\title{
Stratospheric ozone climatology and variability over a southern subtropical site: Reunion Island $\left(21^{\circ} \mathrm{S} ; 5^{\circ} \mathrm{E}\right)$
}

\author{
V. Sivakumar ${ }^{1, *}$, T. Portafaix ${ }^{1}$, H. Bencherif ${ }^{1}$, S. Godin-Beekmann ${ }^{2}$, and S. Baldy ${ }^{1}$ \\ ${ }^{1}$ Laboratoire de l'Atmosphère et des Cyclones, UMR CNRS 8105, Université de La Réunion, Reunion Island, France \\ ${ }^{2}$ Service d'Aéronomie, UMR CNRS 7620, Paris, France \\ " now at: National Laser Centre, Council for Scientific and Industrial Research (CSIR), P.O. Box: 395, Pretoria, South Africa
}

Received: 27 March 2007 - Revised: 2 October 2007 - Accepted: 5 November 2007 - Published: 29 November 2007

\begin{abstract}
The study presents the climatological characteristics of stratospheric ozone observed over Reunion Island using in-situ (ozonesonde and SAOZ) and satellite (UARSHALOE, SAGE-II and TOMS) measurements. It uses colocalised ozonesondes (from September 1992 to February 2005) and SAOZ measurements (from January 1993 to December 2004), SAGE-II data from October 1984 to February 1999 ( $\sim 15$ years), HALOE data from January 1991 to February 2005 ( $\sim 15$ years), and NIMBUS/TOMS data from January 1978 to December 2004 (27 years). The satellite measurements correspond to overpasses located nearby Reunion Island $\left(21^{\circ} \mathrm{S} ; 55^{\circ} \mathrm{E}\right)$. The height profiles of ozone concentration obtained from ozonesonde $(0.5-29.5 \mathrm{~km})$ show less bias in comparison with the HALOE and SAGE-II measurements. Though, the satellite (HALOE and SAGE-II) measurements underestimate the tropospheric ozone, they are in good agreement for the heights above $15 \mathrm{~km}$. The bias between the measurements and the normalized ozone profile constructed from the ozonesonde and SAGE-II satellite measurement shows that the SAGE-II measurements are more accurate than the HALOE measurements in the lower stratosphere. The monthly variation of ozone concentration derived from ozonesonde and HALOE shows a nearly annual cycle with a maximum concentration during winter/spring and minimum concentration during summer/autumn months. The time evolution of total column ozone obtained from TOMS, SAOZ and the one computed from ozonesonde and SAGE-II, exhibits similar behaviour with analogous trends as above. The TOMS variation displays a higher value of total column ozone of about 3-5 DU (10\%) in comparison with the SAOZ and the integrated ozone from ozonesonde and SAGE-II.
\end{abstract}

Correspondence to: V. Sivakumar

(svenkataraman@csir.co.za)
Keywords. Atmosphere composition and structure (Middle atmosphere - composition and chemistry) - Meteorology and atmospheric dynamics (Climatology; Middle atmosphere dynamics; Tropical meteorology; Instruments and techniques)

\section{Introduction}

Ozone plays an important role in the earth's radiation budget by preventing UV radiation from penetrating the earth's atmosphere. The stratosphere is a region in the earth atmosphere which exhibits maximum ozone concentration and helps to prevent UV radiation from penetrating the atmosphere and the earth surface (see review article by Staehelin et al., 2001). On the other-hand, the troposphere ozone concentration acts as an atmospheric pollutant and leads to global warming. Therefore, understanding ozone concentration variations in the stratosphere and troposphere height regions is of great importance to the research community.

There are different remote sensing instruments to provide vertical ozone profiles, such as spectrometers, ozonesondes, lidars, etc. Ozonesondes are recognized to be an effective tool for measuring ozone in the troposphere and part of the stratosphere (Beekman et al., 1994; Logan, 1999). Logan (1999) investigated the ozone variation in the lower stratosphere using ozonesonde data from the northern hemisphere and observed that the amount of ozone decreases between the tropopause and $100 \mathrm{hPa}$ from March to September due to an increase in the tropopause height. Fujiwara et al. (2000) provided the seasonal variations of troposphere ozone over Indonesia (Watukosesk, $7.5^{\circ} \mathrm{S} ; 112.6^{\circ} \mathrm{E}$ ) using 5 years of ozonesonde measurements. The seasonal variations showed an enhanced ozone-mixing ratio during dry season (AugustNovember), in comparison with the other seasons which is

Published by Copernicus Publications on behalf of the European Geosciences Union. 
most likely caused by biomass burning. Their results are in accordance with the observations made over the equatorial eastern pacific, Cristobal, Galapagos $\left(0.9^{\circ} \mathrm{S} ; 89.6^{\circ} \mathrm{W}\right)$ by Shiotani et al. (2002). A review by Staehelin et al. (2001) addressed that the satellite and ground-based measurements show no significant ozone trends in the tropics but significant long-term negative trends of 2-4\% in the northern and southern mid-latitudes. Brinksma et al. (2002) observed annual trends in troposphere-stratosphere ozone variation using five years of ozone measurements from lidar, ozonesonde and satellite data over a mid-latitude station, Lauder $\left(45^{\circ} \mathrm{S}\right.$; $\left.170^{\circ} \mathrm{E}\right)$. They have observed high concentrations during winter. Using Southern Hemisphere ADditional OZonesonde (SHADOZ), Thompson et al. (2003b) presented the troposphere ozone climatology using 3 years of ozonesonde observations for different stations over southern hemisphere. The observations are concentrated especially over tropics/subtropical station and noticed a maximum ozone concentration during the winter/spring period.

Although the ozonesonde measurements are precise for the troposphere and lower stratosphere height regions, they are unable to provide a global picture (Barnes et al., 1985; Tiao et al., 1986). On the other hand, satellite measurements provide a global coverage with very low frequency of observation requirements for a particular site. The Halogen Occultation Experiment (HALOE) on UARS and Stratospheric Aerosol and Gas Experiment (SAGE) provide a relatively better estimation of ozone with good vertical resolution, even at tropospheric altitudes, though less in frequency of observations for a given site. Lu et al. (1997) compared HALOE, SAGE-II and ozonesonde data from Northern hemisphere (Payerne; $46.8^{\circ} \mathrm{N}, 6.95^{\circ} \mathrm{E}$ ) and Southern hemisphere (Lauder; $45.0^{\circ} \mathrm{S}, 169.68^{\circ} \mathrm{E}$ and Macquarie Island; $\left.54.5^{\circ} \mathrm{S}, 158.95^{\circ} \mathrm{E}\right)$. Their studies suggested that HALOE, SAGE-II and ozonesonde measurements are in good agreement; especially above $20 \mathrm{~km}$. Bhatt et al. (1999) concluded that HALOE is providing accurate ozone profile in the lower stratosphere whilst the correction for aerosols interference is well characterized and when there is no cirrus layers detected. Newchurch et al. (2000), using SAGE-I/II data for longer period of about 20 years (1978-1998), noted that the maximum decline in ozone trends occurred at $\sim 40 \mathrm{~km}$. The studies further evidenced a large negative trends present for the extra-tropics $(-1.0 \% /$ year $)$ compared to the tropics (-0.6\%/year). Dorokhov et al. (2002) stated that the comparison between satellite and ground-based measurements permits a better understanding of the characteristics and weakness of each data set.

Besides, height profiles of ozone, the total columns of ozone have been studied by various researchers. Chandra et al. (1996) presented the mid-latitude total ozone trends in the northern hemisphere and noticed that they are influenced by inter annual variability which is associated with dynamical perturbations in the atmosphere during the winter and spring months. They also estimated that due to both radia- tive and dynamical processes, a strong positive correlation between total ozone and lower stratospheric temperatures exists. Ziemke and Chandra (1999) discussed the significance of biomass burning in generating seasonal and zonal anomalies in total ozone over tropics using 20 years of total ozone mapping spectrometer (TOMS) data. Their study illustrated an annual cycle with a maximum ozone concentration during September and October from $15^{\circ} \mathrm{N}$ to $15^{\circ} \mathrm{S}$. The biomass burning was found to occur at different times for northern and southern hemispheres. However, recent studies based on three-dimensional atmospheric chemistry and transport models suggest that photochemical ozone formation due to biomass may be less important (Lelieveld and Dentener, 2000; Marufu et al., 2000; Moxim and Levy, 2000; Chandra et al., 2002).

It is apparent from all the above recent studies that there is considerable interest within scientific community to study the substantial decrease/increase in stratosphere/troposphere ozone. Over tropical and sub-tropical regions, the ozone measurements are very few, especially in the southern hemisphere (WMO, 1999, Staehelin et al., 2001), though it has a significant contribution in the global climate change. Reunion Island $\left(21^{\circ} \mathrm{S} ; 55^{\circ} \mathrm{E}\right)$ is located over southern subtropics and is influenced by a number of atmospheric perturbations, such as cyclone, Inter Tropical Convective Zone (ITCZ) passages, strong jet streams etc, where the study on ozone variations play an important role in addressing different aspects of the climate. In this study, we report on the climatological characteristics of stratospheric ozone over Reunion Island $\left(21^{\circ} \mathrm{S} ; 55^{\circ} \mathrm{E}\right)$ using in-situ ozonesonde data (13 years) and its comparison with UARS-HALOE data (15 years). The study also attempted to validate the SAOZ measurements taken over Reunion Island by comparing with total ozone measurements from TOMS and those obtained by integrating ozonesonde and SAGE-II data (hereafter OAS). The paper is organized as follows; Sect. 2 provides a brief sketch on data used; Sect. 3 presents the climatological results obtained from ozonesonde and HALOE, comparison between the ozone measurements from ozonesonde and HALOE, temporal evolution of ozone and anomalies between the measurements and comparison of total column ozone measurements from TOMS and SAOZ; Sect. 4 summarizes and concludes the results. In addition, an appendix is included and it provides the monthly mean climatological value of ozone concentration and standard deviation over Reunion Island for the height region from ground to $30 \mathrm{~km}$.

\section{Data}

\subsection{Ozonesonde data}

The radiosonde accompanied with Electrochemical Concentration Cell (ECC) is used for measuring height profiles of ozone from sea level to about $30 \mathrm{~km}$. The radiosondes were 
launched twice a month from September 1992 to December 1999 and once a week from January 1999 to at-present. The recorded ozone measurements are converted to concentrations $\left(\mathrm{mol} / \mathrm{cm}^{3}\right)$ and used for the present study. The data has also been collected regularly on both SHADOZ and Network for Detection of Atmospheric Composition and Change (NDACC) programmes. More details about the data and quality of ozonesonde measurements are found in the literature (Fujiwara et al., 2000; Thompson et al., 2003a, b) and also specifically for the Reunion ozonesonde measurements (Baldy et al., 1996; Randriambelo et al., 2000 and Sivakumar et al., 2006).

We use 13 years of ozonesonde data gathered from September 1992 to February 2005 and the height region from ground to $30 \mathrm{~km}$. The monthly distributions of data are presented in the Fig. 1 (grey colored bars).

\subsection{HALOE-UARS satellite data}

HALogen Occultation Experiment (HALOE) was launched on the Upper Atmosphere Research Satellite (UARS) spacecraft on 12 September 1991, as a part of the Earth Science Enterprise (ESE) program. The experiment uses solar occultation to measure the vertical profile of minor constituents $\left(\mathrm{O}_{3}, \mathrm{H}_{2} \mathrm{O}, \mathrm{NO}_{2}, \mathrm{HCl}, \mathrm{HF}, \mathrm{NO}\right.$, and $\left.\mathrm{CH}_{4}\right)$, aerosol concentrations and temperature with a height resolution of $3.7 \mathrm{~km}$ for an instantaneous field of view of $1.6 \mathrm{~km}$ at the earth limb. It uses the atmospheric transmission measurements in the $2.8 \mu \mathrm{m} \mathrm{CO} \mathrm{CO}_{2}$ band for the retrieval of ozone mixing ratio. The retrieval method applies a simple "onion-peel" procedure to stabilize the height profile at top and bottom. The obtained ozone profiles are accurate for the height range from $10 \mathrm{~km}$ to $90 \mathrm{~km}$, with a possible error of 5 to $10 \%$. More details about HALOE data analysis and quality are discussed in the following literature (e.g., Russell et al., 1993, Randel et al., 1995, Brühl et al., 1996, Cunnold et al., 1996, Natarajan and Callis, 1997, Grooss et al., 1999 and Rood et al., 2000; Remsberg et al., 2001) and can be cited at http://haloedata.larc.nasa.gov/home/index.php site.

The present study uses 15 years (September 1991 to February 2005) of data (version 19), acquired during the passage of HALOE satellite over Reunion $\left(21^{\circ} \mathrm{S}, 55^{\circ} \mathrm{E}\right)$, with latitudinal and longitudinal discrepancies of $\pm 5^{\circ}$ and $\pm 25^{\circ}$. The monthly distributions of data are sketched in the Fig. 1 (shaded bars).

\subsection{SAGE-II satellite data}

Stratospheric Aerosol and Gas Experiment II (SAGE-II) was initiated into the Earth Radiation Budget Satellite (ERBS) in October 1984. The instrument uses the solar occultation technique to measure attenuated solar radiation of the Earth's limb. The transmittance measurements are inverted using the "onion-peel" approach to yield 1-km vertical resolution profiles of aerosol extinction, ozone, nitrogen dioxide and water

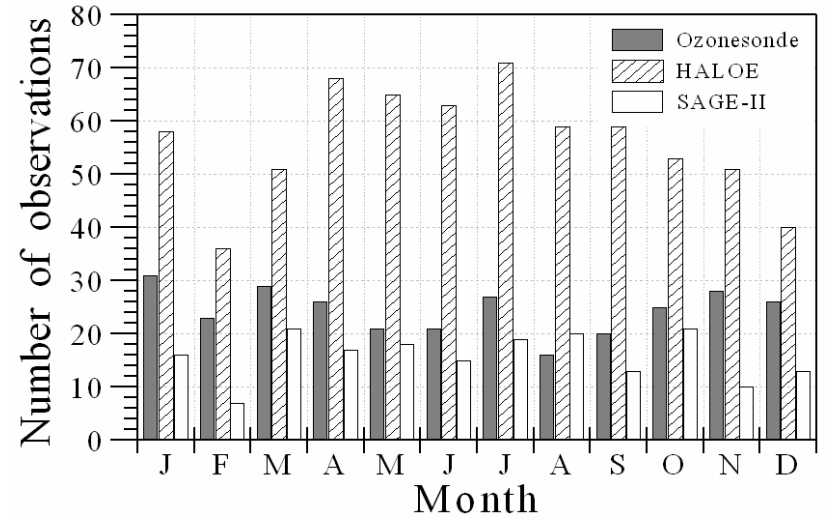

Fig. 1. Histogram represents the monthly distribution of ozonesonde, HALOE and SAGE-II satellite data used for the present study and for the period from 1992 to 2005.

vapour. Extensive validation efforts were made to verify the accuracy of these measurements and the data sets are now archived and available for general scientific use. More details on SAGE-II data could be found in Attmannspacher et al. (1989) and Cunnold et al. (1989).

SAGE-II ozone measurements for the height range from $0.5 \mathrm{~km}$ to $70.5 \mathrm{~km}$ and for the period from October 1984 to February 1999 ( $\sim 15$ years) is used, here. The overall constructed monthly mean profiles are used to merge with daily ozonesonde measurement, so that the ozone profiles extend from $0.5 \mathrm{~km}$ to $70.5 \mathrm{~km}$, and also to allow for the computation of the corresponding total columns of ozone. The monthly distributions of data are presented in the Fig. 1 (blank bars).

\subsection{TOMS satellite data}

Total Ozone Mapping Spectrometer (TOMS) measures the total ozone content of the Earth's atmosphere. The instrument was first launched on the Nimbus 7 Spacecraft in 1978 followed by Meteor and Earth Probe. The nominal uncertainties of TOMS ozone data vary from 1 to $3 \%$. Further details on the TOMS data are available at http://toms.gsfc.nasa.gov/ adeos/adeos.html and McPeters et al. (1993).

We use data corresponding to Reunion site $\left(21^{\circ} \mathrm{S} ; 55^{\circ} \mathrm{E}\right)$ obtained from TOMS for the period from July 1996 to December 2004 and the earlier data obtained from NIMBUS-7 from January 1978 to June 1996. The data is used to normalize the ozone profiles by integrating the ozone measurements from ozonesonde and SAGE-II data (OAS) and also to make a comparison with $\mathrm{SAOZ}$ and the total ozone obtained from OAS. 


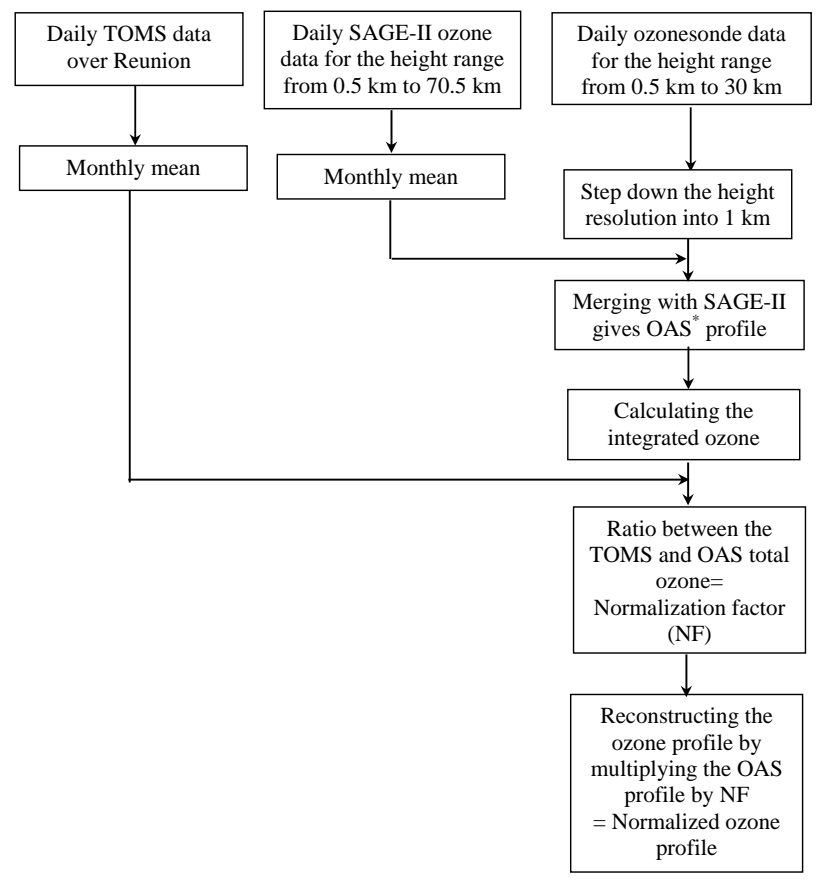

Fig. 2. Flow diagram represents the procedure followed to obtain the normalized ozon profile. OAS refers to the combined ozonesonde and SAGE-II profile.

\subsection{SAOZ data}

The Système d'Analyse par Observation Zénithale (SAOZ) instrument is a broad-band $(290-640 \mathrm{~nm})$ spectrometer and has undergone various developments since 1988 (Pommereau and Piquard, 1994). The earlier documents on intercomparison with different instruments evidenced that the spread in ozone line-of-sight amount is better than 1\% (Pommereau and Piquard, 1994; Hoffman et al., 1995; Vaughan et al., 1997; Roscoe et al., 1999). The vertical columns of ozone are obtained from the line-of-sight columns and air-mass factor (AMF), using the following relationship;

$\mathrm{O}_{3 \text { (vert) }}=\frac{\left(\mathrm{O}_{3 \text { (slant })}+\mathrm{O}_{3 \text { (ref) }}\right)}{\mathrm{AMF}}$

Where, $\mathrm{O}_{3 \text { (ref) }}$ is the reference ozone spectrum obtained from the spectrometer on a clear day at low solar zenith angle. Line-of-sight ozone is identified as slant ozone column $\mathrm{O}_{3 \text { (slant) }}$ and is derived from a spectral band of $100 \mathrm{~nm}$ wide centered at $510 \mathrm{~nm}$. Real-time and re-analysis SAOZ programs use the standard AMF which is calculated from radiative transfer model. The value of AMF is found to vary with latitude and is typically about $1.2 \%$ (ref. Sarkissian, 1992).

Here, the total columns of ozone obtained by SAOZ from January 1993 to December 2004 are used for comparison with both TOMS and the integrated ozone from OAS.

\section{Results}

\subsection{Normalized ozone profile}

A height profile of ozone is constructed for the height region from $0.5 \mathrm{~km}$ to $70.5 \mathrm{~km}$ by combining ozonesonde and SAGE-II measurements which are normalized with total column ozone from TOMS data. Such profile has been used as a reference for comparing with the other measurements. The routine adopted to derive the normalized profile is as follows;

- Daily ozonesonde data is stepped down into $1 \mathrm{~km}$ height resolution.

- Using 15 years (October 1984 to February 1999) of SAGE-II data, the monthly mean ozone profiles are obtained for the height region from $0.5 \mathrm{~km}$ to $70.5 \mathrm{~km}$.

- Similarly, the monthly mean total ozone values for Reunion Island are derived from 27 years of TOMS measurements (from January 1978 to February 2005).

- The ozonesonde and SAGE-II monthly mean profiles (OAS) are merged appropriately for each profile, at $3 \mathrm{~km}$ down to maximum height extended by the ozonesonde, taking into account the measurement error at the higher heights. The SAGE-II monthly mean profiles are correspondingly selected based on the ozonesonde observational date. The merging region $(3 \mathrm{~km})$ uses the mean ozone concentrations from SAGEII and ozonesonde.

- The above constructed OAS profiles are individually integrated in order to retrieve the corresponding total ozone in terms of Dobson units. The normalization factor is defined as the ratio of the OAS total ozone to the corresponding monthly mean TOMS values.

- Thus, the normalized ozone profile for the height region from $0.5 \mathrm{~km}$ to $70.5 \mathrm{~km}$ is derived by multiplying the OAS profile by normalization factor.

The above explained steps are demonstrated in a simplified flow chart (see Fig. 2). It is also noted here that the calculated normalization factor for the complete datasets from ozonesonde, SAGE-II and TOMS data, is found to vary from 1.02 to 1.09 with an overall standard deviations of $\sim 0.02$.

\subsection{Height profile of mean ozone}

Height profiles of mean ozone concentrations obtained from ozonesonde, HALOE and SAGE-II measurements are presented in Fig. 3. This figure illustrates the accuracy of ozone measurements obtained from ozonesonde (in-situ), HALOE and SAGE-II satellite data. It also validates the ozone measurements and illustrates the respective instrumental error and relative measurement differences. Here, the ozonesonde measurements corresponds to the height region 
from $0.5 \mathrm{~km}$ to $29.5 \mathrm{~km}$ and the HALOE and SAGE-II satellite data range from $0.5 \mathrm{~km}$ to $70.5 \mathrm{~km}$. Since the height resolution of the SAGE-II measurements is $1 \mathrm{~km}$, the HALOE and ozonesonde data has also been stepped down to $1 \mathrm{~km}$ resolution for uniformity. Utilizing the above data, the overall mean ozone profiles are constructed, individually for each instrument irrespective of the year and month.

Figure 3a displays the height profiles of ozone concentrations obtained from ozonesonde, SAGE-II and HALOE. The figure is superimposed with the height profile of normalized ozone concentrations which were obtained by the above illustrated method. Few differences in values are noticed due to different instruments and techniques. The normalized ozone profiles illustrate a very close agreement between the ozonesonde and SAGE-II satellite data, indicating that the measurements are consistent. The normalized ozone profile is in accordance to the ozonesonde measurements in the lower troposphere and with SAGE-II and HALOE profiles in the stratosphere up to about $40 \mathrm{~km}$. Above $40 \mathrm{~km}$, the SAGE-II and HALOE measurements indicate very little discrepancy in the ozone measurements. The maximum ozone concentration, $\sim 4.5 \times 10^{12} \mathrm{~mol} / \mathrm{cm}^{3}$ is displayed by all the instruments at $\sim 26 \mathrm{~km}$. It also shows a small difference in the estimated ozone concentration by instrument, SAGEII and HALOE show similar values and are $~ 3 \%$ higher than the ozonesonde. It is also clear from the Fig. 3a that SAGEII and HALOE are underestimating the ozone values in the lower tropospheric height region (below $10 \mathrm{~km}$ ), as expected from the satellite instruments which measure from top to bottom and the error increases downward in the troposphere (see also Fig. 3b). Relatively, the SAGE-II measurements provide a reasonable comparison with ozonesonde above $12 \mathrm{~km}$ when compared to the HALOE which are in agreement above $18 \mathrm{~km}$.

The relative percentage of deviation (bias) in the ozone measurements by ozonesonde, HALOE and SAGE-II with respect to the normalized ozone profile is calculated using the following expression:

$\mathrm{O}_{3 \text { (bias) }}=\frac{\left(\mathrm{O}_{3(\text { nor })}-\mathrm{O}_{3(\mathrm{xxx})}\right)}{\mathrm{O}_{3(\mathrm{nor})}} * 100.0$

Where, " $\mathrm{O}_{3(\mathrm{xxx})}$ " refers to the ozone measurements from ozonesonde, HALOE or SAGE-II.

The calculated bias in ozone measurements is presented in Fig. 3b. In other words, it displays the relative differences/uncertainty in the ozone measurements. The figure substantiates the underestimation of ozone measurements in the lower troposphere by HALOE and SAGE-II. It shows that the ozone measurements in the troposphere obtained from ozonesonde are having a lower bias than those obtained from HALOE and SAGE-II. Just below the ozone maximum height, SAGE-II shows the highest bias while ozonesonde reveals the lowest one.

The ozonesonde measurements illustrate that the bias is within $4-6 \%$ in the lower troposphere height region and a
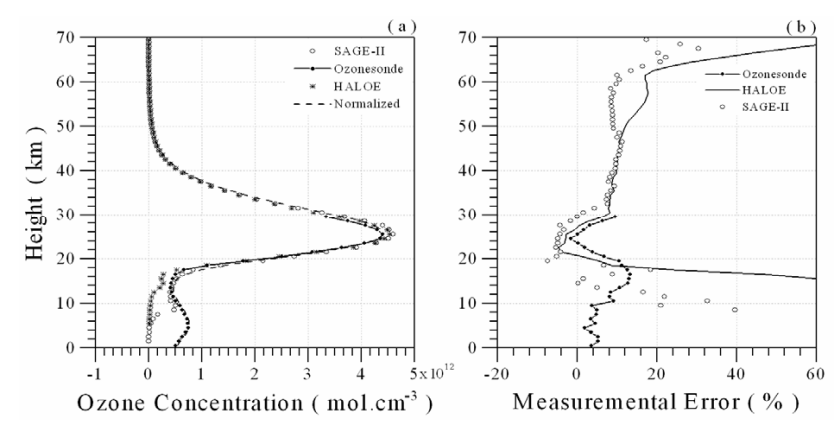

Fig. 3. (a) Height profile of overall mean ozone concentration obtained from ozonesonde, SAGE-II and HALOE. The figure is superimposed with a normalized ozone concentration obtained from ozonesonde and SAGE-II. (b) Height profile of relative percentage of bias in the ozone concentrations measured by ozonesonde, SAGE-II and HALOE with respect to the normalized ozone profile. The percentage of bias is the ratio between the difference in ozone values and the normalized ozone profile.

higher bias of about $10-12 \%$ is noticed in the upper troposphere and lower stratosphere height region $(18-32 \mathrm{~km})$. Such differences are also remarkably less in comparison with day to day variations (standard deviation). Whereas, both the satellite (HALOE and SAGE-II) measurements demonstrate almost the same magnitude of relative difference and is more than $40 \%$ in the lower troposphere. However, the bias is lower and of almost the same magnitude in the stratosphere height region ( above $20 \mathrm{~km}$ ). The satellite and ozonesonde measurements exemplify a high difference in the ozone measurement in the lower stratosphere $(18-32 \mathrm{~km})$ with maximum differences of $-6 \%$ at $\sim 24 \mathrm{~km}$.

The earlier reports on SAGE-II measurement illustrated that the error in ozone retrieval rapidly increases up to approximately $40 \%$ at $10 \mathrm{~km}$ (McCormick et al., 1989; Brinksma et al., 2000) which is in accordance with the result presented here. Brinksma et al. (2000) concluded that the SAGE-II ozone measurements become less consistent with decreasing altitude. The inter-comparison study by $\mathrm{Lu}$ et al. (1997) also provided similar results by showing the difference between HALOE and ozonesonde. These differences were found to be $\sim 10-20 \%$ in the $15-20 \mathrm{~km}$ altitude range, $\sim 10 \%$ in the $20-25 \mathrm{~km}$ altitude range, and $\sim 1-10 \%$ in the $25-30 \mathrm{~km}$ altitude range. Analogously, Cunnold et al. (2000) expressed a resembling result, when they compared the ozonesonde data with SAGE-II and found that SAGE-II values are $\sim 20-30 \%$ larger than the ozonesonde values in the $12-15 \mathrm{~km}$ altitude range. Their observation concluded that the SAGE-II overestimation is due to aerosol loading in the stratosphere height region and measuremental uncertainties. In addition, the very low relative difference in ozonesonde data may be due to the lower accuracy of the ozone sensor in the stratosphere height region. Few published results on the accuracy of ozonesonde noted that the 

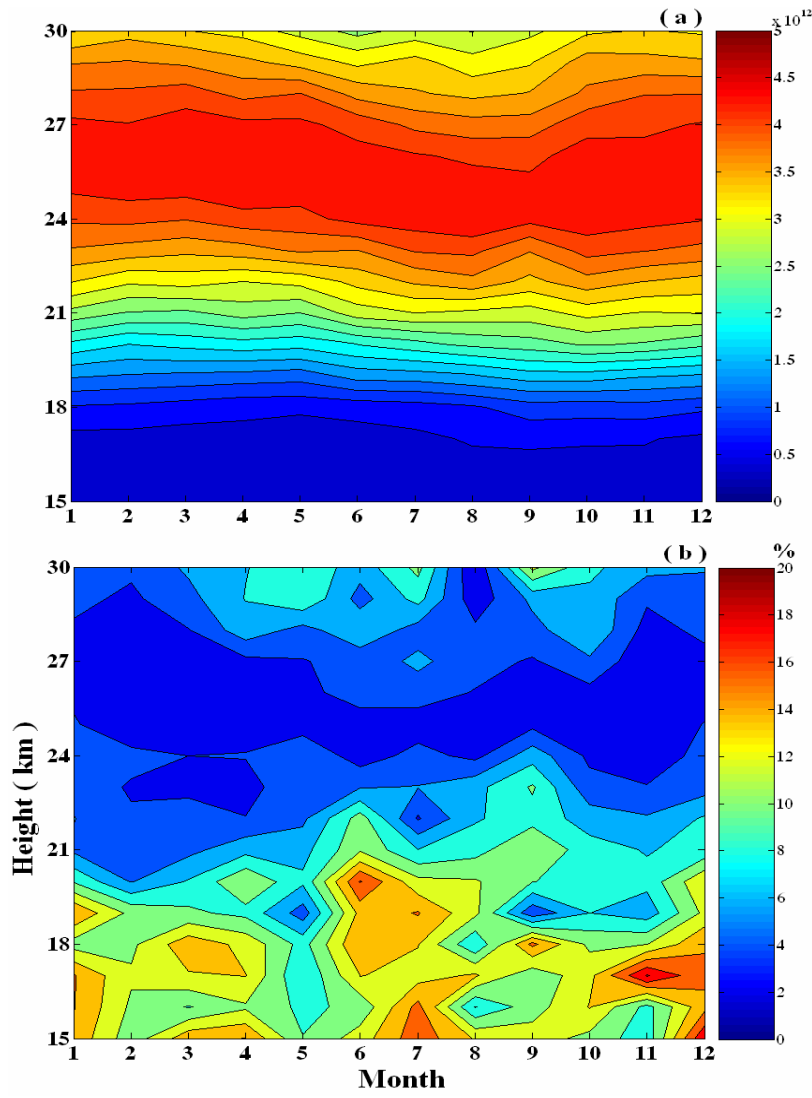

Fig. 4. (a) Height-Month-mean ozone concentration plot and (b) percentage of deviation obtained from ozonesonde measurements. The percentage of deviation is the ratio between the obtained standard deviation and the respective monthly mean value.

accuracy of ECC sonde is $\pm 5 \%$ in the stratosphere region (Beekman et al., 1994; Komhyr et al., 1995; WMO, 1998; Logan, 1999).

\subsection{Seasonal variation of ozone from ozonesonde data}

Since the objective of the paper is to present the stratosphere ozone climatology and its variability at a subtropical site (Reunion Island), the monthly mean ozone variations are presented for the height region from $15 \mathrm{~km}$ to $30 \mathrm{~km}$. The monthly mean ozone values are obtained by grouping the ozonesonde data in terms of month and irrespective of the year. We also segregated the ozonesonde data by subjecting qualitative analysis (i.e., within $\pm 2 \sigma$ ). Hence, the data has better accuracy and the obtained monthly mean profiles are away from the unusual spectacular events (like, high ozone during STE, cyclone, planetary wave breaking).

Figure $4 \mathrm{a}$ displays the monthly mean variations of ozone concentration obtained from ozonesondes for the height region from $15 \mathrm{~km}$ to $30 \mathrm{~km}$. The vertical ozone variations are in the range from $0.5 \times 10^{12}$ to $4.5 \times 10^{12} \mathrm{~mol} / \mathrm{cm}^{3}$. The ozone concentration increases gradually to a maximum in the height range from 24 to $28 \mathrm{~km}$, and then decreases, as expected. The annual or semi-annual variation at any particular height re- gion is not distinguishable, but mostly, it exhibits an annual variation with maximum and minimum ozone concentrations during spring/winter and autumn/summer, respectively. In the Upper troposphere, the obtained seasonal variation is in agreement with the earlier reported troposphere ozone climatology over Reunion with high- and low-ozone concentrations during spring and autumn (Randriambelo et al., 2000 and Thompson et al., 2003b). The result from southern midlatitude station, Lauder $\left(45^{\circ} \mathrm{S}, 170^{\circ} \mathrm{E}\right)$ also observed the annual cycle in upper troposphere ozone densities and stated that due to ozone production by photochemistry and the minimum ozone during winter is due to low solar radiation $(\mathrm{Fu}-$ jiwara et al., 2000). They also stated that the local dynamical activities such as, monsoon circulations, equatorial gravity waves, Kelvin waves and planetary waves may enhance the troposphere ozone concentrations. The seasonal variation of Reunion stratospheric ozone illustrating increase in spring (see Fig. 4a) might be related to wave propagation into the stratosphere (when winds are westerly). The relation between the ozone concentration and QBO phase (easterly/westerly) are delineated in detail in the Sect. 3.6. Further, the Fig. 4a exemplifies the width of the maximum ozone concentration region $\left(\sim 4.5 \times 10^{12} \mathrm{~mol} / \mathrm{cm}^{3}\right)$ which is broad and becomes thinner by September.

The ozone variability in terms of percentage of deviation is presented in Fig. 4b. The percentage of deviation is calculated in terms of ratio between the standard deviation and the respective monthly mean ozone value. Broadly, the obtained seasonal variations in terms of deviations are in the range from 0 to $15 \%$. A very low deviation of less than $5 \%$ is recorded for all the months in the height region from $25 \mathrm{~km}$ to $28 \mathrm{~km}$. High deviations of about $\sim 10-15 \%$ are obtained in the height region from 15 to $21 \mathrm{~km}$. This height region (15 to $21 \mathrm{~km}$ ) is corresponding to the ozone tropopause where much variability in ozone concentration is expected (Sivakumar et al., 2006). Above, in the middle stratosphere, the percentage of deviation is found to be low and a very low deviation (near to $0 \%$ ) is seen from $25 \mathrm{~km}$ to $28 \mathrm{~km}$ over all the months. It may relate to the less fluctuation in ozone concentrations at this height range.

Moreover, it is known that variability of stratospheric ozone depends on chemical and dynamical processes. Indeed, with regard to Reunion geographical position in the southern subtropics, nearby dynamic barriers, such as tropopause and subtropical barrier, ozone in the stratosphere is expected to show high variability due to dynamical processes such as stratosphere-troposphere exchanges and meridian exchanges between the stratospheric tropical reservoir and mid-latitudes, as reported by Baray et al. (1999, 2000), Bencherif et al. (2003), Portafaix et al. (2003) and Semane et al. (2006). Both of these transport mechanisms (vertical transport through the tropical tropopause and isentropic transport nearby the southern subtropical barrier) may be induced by gravity waves and Rossby planetary waves breaking. 


\subsection{Seasonal variation of ozone: HALOE data}

The archived 15 years (January 1991 to February 2005) of ozone measurements from HALOE satellite overpasses nearby Reunion Island $\left(21^{\circ} \mathrm{S}, 55^{\circ} \mathrm{E}\right)$ is grouped in terms of months irrespective of the year. Thereafter the corresponding monthly mean ozone concentrations and the respective relative standard deviations are derived and presented in Fig. 5a and $b$. The monthly distribution of data used for constructing the mean ozone value is displayed in the Fig. 1. Figure 5a represents the monthly variation of ozone, nearly similar as depicted from the ozonesonde measurements (Fig. 4a). Here too, the high ozone value is displayed in the height region from $24 \mathrm{~km}$ to $28 \mathrm{~km}$. Generally, the monthly variations are found to be smooth in comparison to the ozonesonde measurements. It could be due to the height resolution of the HALOE data which is high (has an initial vertical resolution of $\sim 3.7 \mathrm{~km}$ ). Further, the difference in HALOE and ozonesonde measurement may be due to the HALOE overpass location which has the discrepancies of $\pm 5^{\circ}$ and $\pm 25^{\circ}$. Above $27 \mathrm{~km}$, the estimated ozone concentrations are higher than the ozonesonde measurements. A more detailed significance of differences in the ozone measurements between ozonesonde and HALOE are sketched in the following section (see Sect. 3.5).

Figure $5 \mathrm{~b}$ renders the obtained standard deviation from HALOE measurements. The percentage of deviations is presented in-terms of ratio between the obtained standard deviation and the corresponding monthly mean ozone value. The deviations are found to be in the range from 0 to $35 \%$. The deviations are large for height region from $15 \mathrm{~km}$ to $20 \mathrm{~km}$, particularly from $15 \mathrm{~km}$ to $18 \mathrm{~km}$. The deviation is relatively high during January, April, July and November. At and above $20 \mathrm{~km}$, the deviations are smaller in comparison with the ozonesonde deviation (Fig. 4b). The similarity in the magnitude of the deviation $(\sim 0-5 \%)$ which is noted above $21 \mathrm{~km}$, as illustrated by ozonesonde measurement, further proves the accuracy of both instruments. The observed large deviation in the lower height region, from $15 \mathrm{~km}$ to $18 \mathrm{~km}$ may be due to the lower accuracy of ozone estimation by HALOE (also see Fig. 3b). It is consistent with the report by Borchi et al. (2004) revealing that the HALOE measurements are not reliable for tropical upper troposphere, especially below $22 \mathrm{~km}$. This is also true for the SAGE-II measurements (Morris et al., 2002). Brühl et al. (1996) determined that the HALOE ozone mixing ratio may have measurement errors of about $30 \%$ at $100 \mathrm{hpa}$ and about $8 \%$ at $1 \mathrm{hpa}$ pressure levels. An earlier study on quality of HALOE ozone measurements in the stratosphere reveals that the uncertainty in measurements is due to the forward model which is used to correct ozone concentrations retrieval and remove aerosol interference (Bhatt et al., 1999).

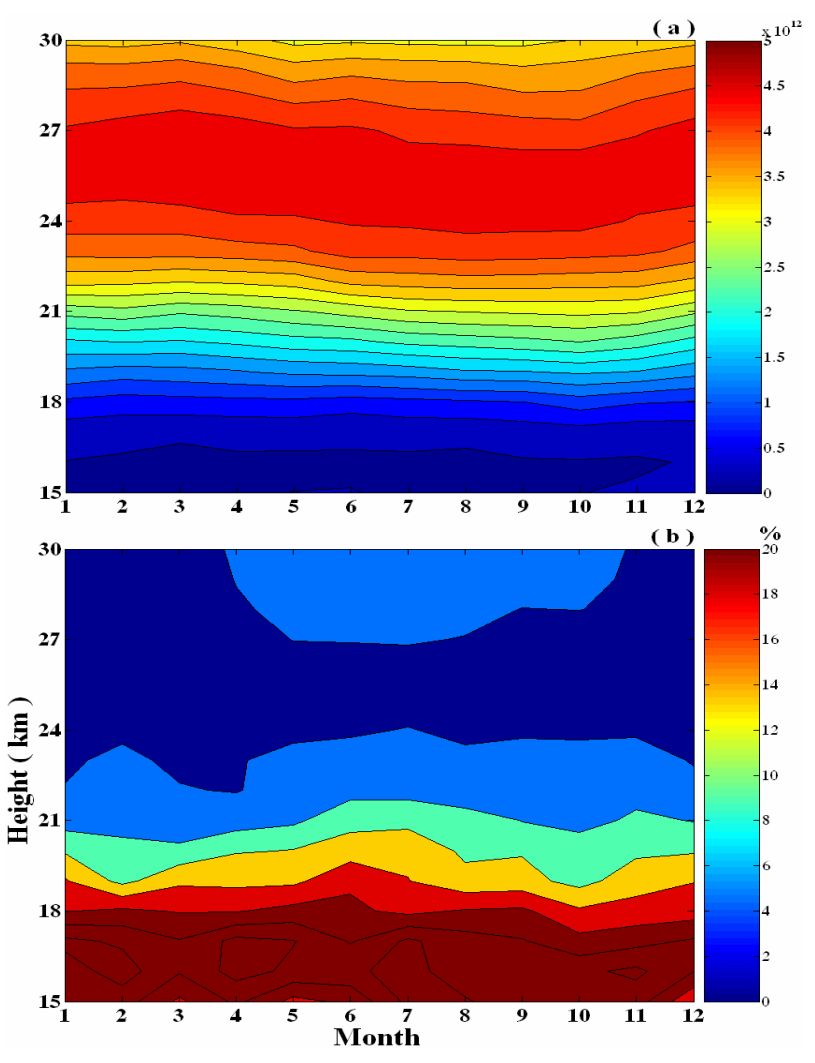

Fig. 5. Same as Fig. 4 but for the HALOE satellite data.

3.5 Difference between ozonesonde and HALOE measurements

The percentage of difference between the measured ozone concentrations is obtained from ozonesonde and HALOE observations. The percentage of difference is calculated with respect to the ozonesonde observations, i.e.,

$\mathrm{O}_{3 \text { (bias) }}=\frac{\left(\mathrm{O}_{3 \text { (Sonde })}-\mathrm{O}_{3 \text { (Haloe })}\right)}{\mathrm{O}_{3 \text { (Sonde })}} * 100.0$

Figure 6 represents the obtained percentage of difference between the ozonesonde and HALOE measurements. It shows that for almost all the months, the differences vary from -20 $\%$ to $+60 \%$ with positive and high values between $15 \mathrm{~km}$ and $17.5 \mathrm{~km}$. It further confirms the result obtained from the normalized profile, as depicted in Fig. 3b, showing the low accuracy of HALOE ozone measurements in the upper troposphere. Lu et al. (1997) compared ozone measurements from ozonesonde, SAGE-II and HALOE. They found a similar kind of difference in the measurements. Their result epitomized an increase in relative differences with respect to ozonesonde with decreasing altitude. The differences were found to be high in the height region from 15 and $20 \mathrm{~km}$. It might be due to different techniques followed by satellite and ozonesonde. Also, their observations illustrated that the 


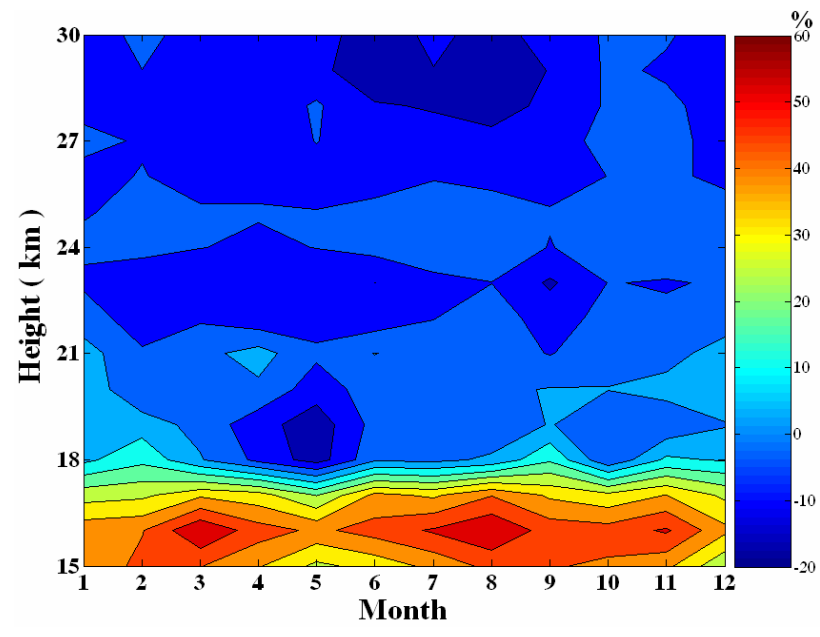

Fig. 6. The monthly mean percentage of differences in between HALOE and ozonesonde with respect to the ozonesonde value.

HALOE data obtained by version 18 is better than that obtained by version 17 . We have used version 19 of HALOE data, which may further improved the estimation.

\subsection{Monthly evolution of ozone and its relation with QBO}

The monthly mean ozone concentrations for the period from 1992 to 2004 have been derived from ozonesonde and HALOE data. The height-time cross-section of monthly mean ozone concentrations from ozonesonde and HALOE measurements are displayed in Fig. 7a-b and their corresponding percentages of difference with respect to the overall monthly mean values are presented in Fig. $7 \mathrm{~d}$ and e. The HALOE measurements are presented for the $15-45 \mathrm{~km}$ height region while the ozonesonde measurements are given between $15-$ and $30-\mathrm{km}$. Generally, the mean ozone concentration from ozonesonde and HALOE are increasing with height from 15 to $24 \mathrm{~km}$ and then decreases above $27 \mathrm{~km}$. The high ozone concentration is displayed from $\sim 21 \mathrm{~km}$ to $27 \mathrm{~km}$ with localized maximum value at about $27 \mathrm{~km}$. In comparison to the ozonesonde measurement, the HALOE satellite measurements show modest difference in ozone concentrations values less than $\pm 5 \%$. The low ozone values obtained from ozonesonde at higher height regions could be due to lower measuremental accuracy and the accuracy increases with decrease in height. The monthly evolutions of ozone concentration represent annual oscillation with maximum and minimum during May and December months. It is also apparent from the figure that the monthly variations of HALOE ozone values are not much different for the height region from 18 to $21 \mathrm{~km}$ when compared with the height region between 24 and $27 \mathrm{~km}$. This may be related to (1) the fact that satellite measurements are made following a downward scan (from top to bottom), (2) to the corresponding uncertainty increases with decreasing height, (3)
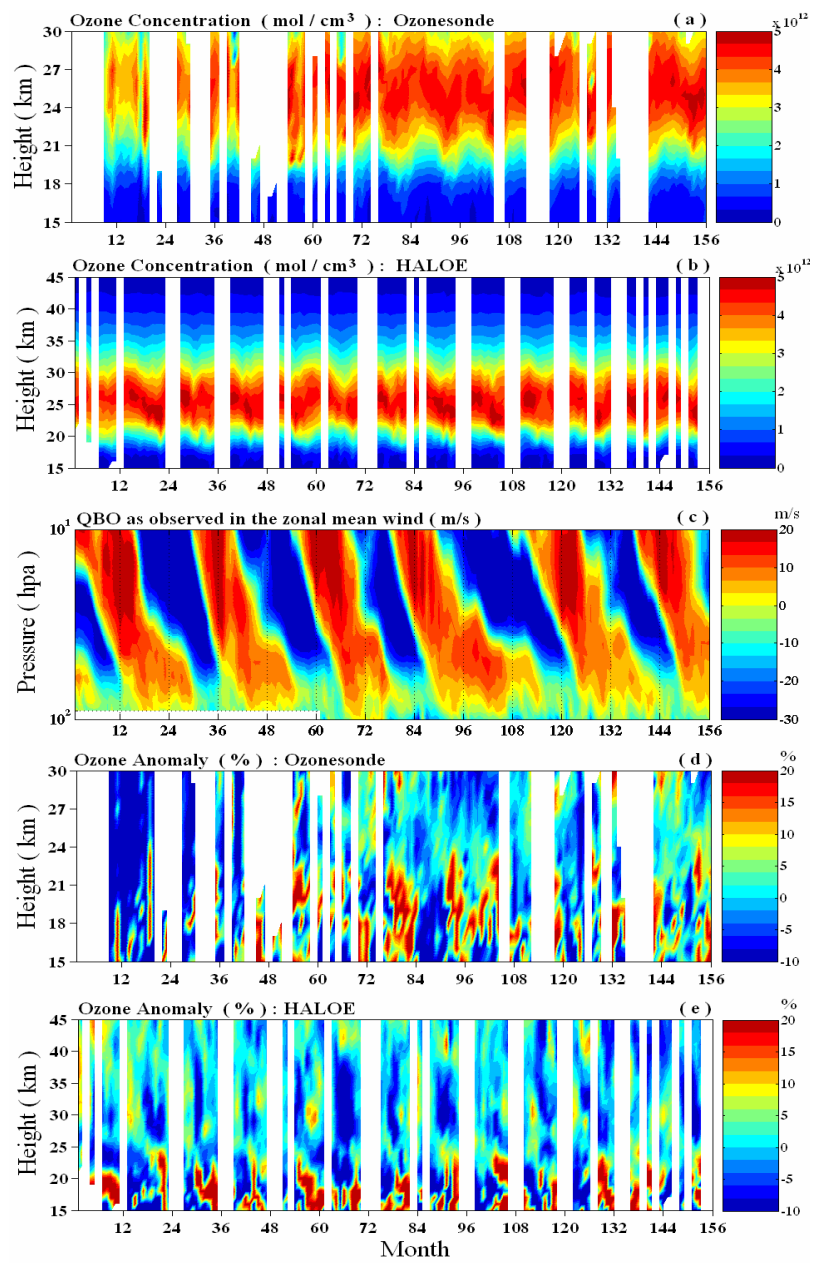

Fig. 7. (a-b) Height-time-Monthly evolution of ozone concentrations obtained from the ozonesonde and HALOE measurements, (c) QBO phase illustrated from the zonal mean wind over equator (d-e) the ozone anomalies with respect to the overall monthly mean obtained from the ozonesonde and HALOE measurements for the period from January 1992 to December 2004.

to the relative satellite low resolution, and (4) to the possible aerosol interference in $\mathrm{O}_{3}$ values retrieval. It is also evident from the Fig. 6 that the HALOE under estimates ozone concentration in the upper troposphere. Though there are gap in the measurements during some years/month and for the ozonesonde and HALOE, both clearly display descending/ascending trends of in the $20-30 \mathrm{~km}$ height region. Such variations are clearer from HALOE measurements than from ozonesonde and it might be caused by quasi-biennial oscillation (QBO) modulation. In order to compare the monthly mean ozone values and the ozone anomalies with quasibiennial oscillation (QBO) structures, the zonal mean wind data for the corresponding period is plotted in Fig. 7c. We use zonal wind data obtained at an equatorial site Singapore $\left(1.30^{\circ} \mathrm{N} ; 103.85^{\circ} \mathrm{E}\right)$. The zonal wind data over equator is 
generally accepted as a representative of the QBO structure and applied by the researchers (see Naujokat, 1986). The ascending/ descending structure of ozone by ozonesonde measurements are found to be related to the easterly/westerly phase of QBO in some years. The years 1999 and 2004, indicate the descending structure of ozone with westerly phase of QBO. The year 1998 illustrates the ascending structure of ozone with easterly phase of QBO. For all the other years, the structure is not very clear from the ozonesonde measurement. It is almost similar for the HALOE measurements, but due to non-availability of ozone data for intermittent months in a year, it is not easy to investigate.

The percentage of deviations or anomalies is obtained for each individual month from the monthly mean ozone values with respect to the corresponding monthly climatological values of ozone. With increasing height, the percentage of anomalies is less and highly reduced at $\sim 24 \mathrm{~km}$, also both the HALOE and ozonesonde measurements show less bias values within $\pm 10 \%$. Both Ozonesonde and HALOE measurements show positive/negative deviations for the heights below/above $21 \mathrm{~km}$. It is also clear from the figure that the observed high anomalies below $21 \mathrm{~km}$ are concurrent with the mentioned high deviation in the monthly mean ozone value as demonstrated from Fig. 4b. Further, the positive/negative percentage of deviations of ozone might be in connection to the QBO with westerly/easterly phases. It is clearer for the HALOE measurements than the ozonesonde measurements. The earlier report from SHADOZ data by Thompson et al. (2003b) observed that the stratospheric ozone profiles do exhibit QBO cycle.

It is also apparent from the figure that neither HALOE nor SAGE-II satellite data do not undertake the local-disturbing event (like, convection activities, cyclones and etc.,), which perturb highly the ozone concentrations. Since, the main objective of the paper is to provide a picture of the climatological variation of ozone with height, we have not discussed these events in detail.

\subsection{Total ozone and comparison with TOMS and SAOZ measurements}

Here, the integrated ozone columns have been obtained from the normalized (the combined ozonesonde and SAGEII measurement) ozone profile. The total ozone time-series are presented in Fig. 8a and the relative percentages of differences with respect to the TOMS values are shown in Fig. 8 b. The relative percentage of difference is calculated for SAOZ and the integrated ozone from OAS with respect to the TOMS data, i.e.,

$\mathrm{O}_{3 \text { (bias) }}=\frac{\left(\mathrm{O}_{3(\mathrm{TOMS})}-\mathrm{O}_{3(\mathrm{xxx})}\right)}{\mathrm{O}_{3(\mathrm{TOMS})}} * 100.0$

The monthly variations in total ozone obtained from the normalized profiles (OAS) are mostly closer to TOMS within
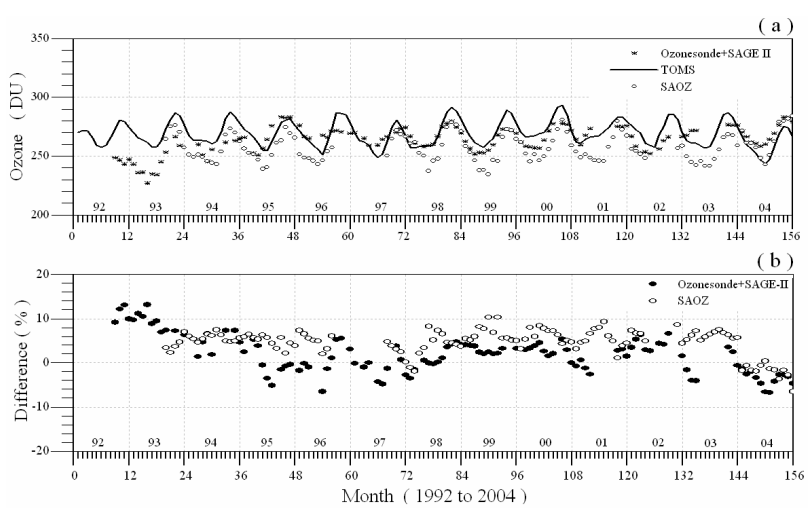

Fig. 8. (a) Monthly mean evolution of integrated ozone values obtained for the period from 1992 to 2004 by TOMS, OAS and SAOZ measurements. (b) The normalized percentage of difference obtained from OAS and SAOZ measurements with respect to TOMS.

$\pm 5 \%$. The total ozone follows an easy-to-spot annual cycle with a maximum during spring (September-October) and a minimum by early winter (May). Such seasonal variations are consistent with other reported results for southern hemisphere sites (Logan and Kirchhoff, 1986; Fishman et al., 1990; Kirchhoff et al., I991; Kim and Newchurch, 1996; Fujiwara et al., 2003).

The ozonesonde measurement during the initial period from September 1992 to December 1993 shows low ozone concentrations (see Fig. 8a). It is also noted from Fig. 8b (TOMS-OAS differences) that during 1992-1995 there is a quite regular decrease. Taking into account the latitudinal spread of Pinatubo aerosols, notably in the Southern Hemisphere, and their effects on ozone in the stratosphere, one can speculate that ozone profiles recorded at Reunion highlight the ozone reduction due to Pinatubo aerosol loading.

The SAOZ total ozone measurements nearly follow that of TOMS, but the values are less than TOMS and OAS. The absence of SAOZ values during September 1996 to August 1997 is due to technical changes: software and spectrometer upgrade. The TOMS observation is found to be higher than the SAOZ and the in-situ observations are in agreement with earlier documented result from southern high latitudes (Newchurch et al., 2000; Kita et al., 2000; Bodeker et al., 2001; Masserot et al., 2002). Earlier works indicated that the TOMS measurements are approximately $1 \%$ higher than the average of 30 northern mid-latitude ground-based stations and the discrepancy is higher at southern mid-latitudes (WMO, 1999).

Newchurch et al. (2000) and Masserot et al. (2002) found a significant excess of total ozone of 10-15 DU in TOMS measurement during cloudy conditions and also investigated the incorrect tropospheric ozone climatology, dynamical and chemical influences, instrument calibration error and the algorithm assumption could be the reason for observed excess in TOMS total ozone. 
The Fig. 8b illustrates that the percentage of difference is within $\pm 10 \%$ and shows that OAS is in better agreement with TOMS than SAOZ, except the post-Pinatubo period (early 1992 to 1993. During the initial period of time from 1992 to 1994 , the OAS expresses a high negative bias more than $\sim 10 \%$ (i.e., the TOMS value is higher than the OAS values) and later we find a nearly positive bias. Comparatively, the SAOZ measurements display difference in the range of $\sim 2-$ $8 \%$ for most of the cases. The overall mean difference between TOMS and OAS is $\sim 2 \mathrm{DU}$ and for TOMS and SAOZ is $\sim 4 \mathrm{DU}$. Thereby, it is evident that the OAS is in better agreement with TOMS than SAOZ. This is in accordance with the statements mentioned in a review article by Staehelin et al. (2001) and a report by Pommereau and Goutail (1988) that the SAOZ measurements are better in the polar regions than in the equator, as it does not require direct solar radiation and the visible absorption by ozone is much less temperature dependent than UV absorption. A comparative study between $\mathrm{SAOZ}$ and other techniques reported that SAOZ is clearly $10-15$ DU lower than other techniques and attributed the differences to the used AMF's factors (Vaughan et al., 1997; Sarkissian et al., 1997). The TOMS ozone measurement illustrating high values of 1-2 DU with OAS is in good agreement with the earlier result from WMO (see WMO, 1999) where they found that TOMS measurement is 1-2\% higher in southern low- and mid-latitude regions (Staehelin et al., 2001).

\section{Summary and concluding remarks}

We presented the general climatalogical characteristics of stratosphere ozone for a southern sub-tropical site (Reunion Island, $21^{\circ} \mathrm{S} ; 55^{\circ} \mathrm{E}$ ) using large databases of in-situ (ozonesonde and SAOZ) and satellite (HALOE, SAGE-II and TOMS) measurements. The ozone measurements by ozonesonde, HALOE and SAGE-II are in agreement with their stated level of uncertainties. The largest relative differences between the satellite and ozonesonde measurements are found in the height region from $15 \mathrm{~km}$ to $20 \mathrm{~km}$, suggesting the underestimation of ozone by HALOE in the troposphere height regions. Unambiguously, both ozonesonde and HALOE satellite measurements revealed the maximum and minimum ozone concentrations during the spring/winter and the autumn/summer months, respectively. Such depicted monthly variations of ozone at heights above and below $26 \mathrm{~km}$ are found to illustrate an opposite cyclic behaviour of maximum and minimum ozone concentrations. The relative difference between the HALOE and ozonesonde measurements, demonstrates a positive/negative values for heights below/above $20 \mathrm{~km}$. The monthly temporal variation of the ozone concentration for the height region from $15-30 \mathrm{~km}$ shows descending/ascending trends and which are in relation to the easterly/westerly QBO phase. The time evolution of total column ozone obtained from TOMS, SAOZ, ozonesonde and SAGE-II (OAS), follows an annual cycle with maximum during May-June months. Relatively, the total column ozone by TOMS displays a high value in comparison with the SAOZ and the integrated ozone from ozonesonde and SAGE-II. The measured OAS total column ozone values are in better agreement with TOMS than SAOZ. The above realized results are found to be in better agreement with other reported results for southern hemisphere's mid- and high-latitude stations. The added appendix at the end provides the monthly mean ozone concentration and its standard deviation for Reunion, which can be further considered as a monthly representative one. 


\section{Appendix A}

\section{Ozone value for Reunion}

Table A1. Monthly mean $\left(\times 10^{12} \mathrm{~mol} / \mathrm{cm}^{3}\right)$.

\begin{tabular}{|c|c|c|c|c|c|c|c|c|c|c|c|c|}
\hline $\begin{array}{l}\text { Height } \\
(\mathrm{km})\end{array}$ & Jan & Feb & March & April & May & June & July & Aug & Sep & Oct & Nov & Dec \\
\hline 1 & 0.43 & 0.44 & 0.45 & 0.53 & 0.57 & 0.67 & 0.66 & 0.63 & 0.68 & 0.64 & 0.53 & 0.47 \\
\hline 2 & 0.44 & 0.47 & 0.47 & 0.54 & 0.58 & 0.67 & 0.69 & 0.70 & 0.70 & 0.67 & 0.56 & 0.56 \\
\hline 3 & 0.57 & 0.60 & 0.57 & 0.59 & 0.59 & 0.67 & 0.66 & 0.76 & 0.83 & 0.84 & 0.77 & 0.71 \\
\hline 4 & 0.70 & 0.58 & 0.67 & 0.71 & 0.58 & 0.67 & 0.69 & 0.84 & 0.86 & 0.95 & 0.93 & 0.79 \\
\hline 5 & 0.62 & 0.61 & 0.68 & 0.66 & 0.61 & 0.67 & 0.67 & 0.83 & 0.86 & 0.95 & 0.89 & 0.86 \\
\hline 6 & 0.63 & 0.66 & 0.67 & 0.69 & 0.57 & 0.67 & 0.66 & 0.86 & 0.83 & 0.91 & 0.83 & 0.86 \\
\hline 7 & 0.62 & 0.64 & 0.63 & 0.64 & 0.57 & 0.65 & 0.73 & 0.69 & 0.76 & 0.81 & 0.85 & 0.74 \\
\hline 8 & 0.68 & 0.58 & 0.54 & 0.60 & 0.57 & 0.58 & 0.70 & 0.68 & 0.72 & 0.82 & 0.81 & 0.68 \\
\hline 9 & 0.64 & 0.59 & 0.49 & 0.54 & 0.53 & 0.52 & 0.59 & 0.63 & 0.70 & 0.78 & 0.74 & 0.68 \\
\hline 10 & 0.47 & 0.47 & 0.44 & 0.49 & 0.52 & 0.53 & 0.54 & 0.57 & 0.64 & 0.69 & 0.72 & 0.60 \\
\hline 11 & 0.48 & 0.40 & 0.39 & 0.47 & 0.46 & 0.49 & 0.47 & 0.46 & 0.56 & 0.51 & 0.58 & 0.52 \\
\hline 12 & 0.38 & 0.37 & 0.38 & 0.45 & 0.45 & 0.45 & 0.36 & 0.44 & 0.53 & 0.55 & 0.53 & 0.43 \\
\hline 13 & 0.39 & 0.37 & 0.38 & 0.42 & 0.40 & 0.42 & 0.35 & 0.39 & 0.42 & 0.48 & 0.50 & 0.46 \\
\hline 14 & 0.39 & 0.41 & 0.38 & 0.41 & 0.37 & 0.42 & 0.40 & 0.40 & 0.39 & 0.51 & 0.50 & 0.40 \\
\hline 15 & 0.42 & 0.45 & 0.45 & 0.40 & 0.39 & 0.43 & 0.39 & 0.44 & 0.41 & 0.49 & 0.49 & 0.43 \\
\hline 16 & 0.45 & 0.39 & 0.45 & 0.43 & 0.39 & 0.48 & 0.49 & 0.52 & 0.48 & 0.50 & 0.52 & 0.49 \\
\hline 17 & 0.52 & 0.52 & 0.49 & 0.50 & 0.44 & 0.49 & 0.55 & 0.62 & 0.66 & 0.63 & 0.62 & 0.55 \\
\hline 18 & 0.82 & 0.79 & 0.72 & 0.67 & 0.65 & 0.69 & 0.72 & 0.81 & 0.97 & 0.96 & 0.98 & 0.89 \\
\hline 19 & 1.37 & 1.31 & 1.28 & 1.23 & 1.20 & 1.43 & 1.46 & 1.56 & 1.71 & 1.72 & 1.61 & 1.55 \\
\hline 20 & 2.01 & 1.82 & 1.91 & 1.98 & 1.92 & 2.08 & 2.23 & 2.38 & 2.47 & 2.59 & 2.54 & 2.38 \\
\hline 21 & 2.74 & 2.55 & 2.52 & 2.68 & 2.57 & 2.95 & 3.07 & 3.00 & 2.95 & 3.15 & 3.04 & 3.07 \\
\hline 22 & 3.32 & 3.10 & 3.16 & 3.07 & 3.13 & 3.39 & 3.60 & 3.73 & 3.49 & 3.71 & 3.55 & 3.46 \\
\hline 23 & 3.78 & 3.70 & 3.62 & 3.69 & 3.85 & 3.80 & 4.08 & 4.11 & 3.82 & 4.14 & 4.06 & 3.98 \\
\hline 24 & 4.09 & 4.12 & 4.07 & 4.20 & 4.21 & 4.38 & 4.43 & 4.54 & 4.37 & 4.46 & 4.39 & 4.31 \\
\hline 25 & 4.34 & 4.41 & 4.39 & 4.50 & 4.42 & 4.44 & 4.54 & 4.43 & 4.35 & 4.52 & 4.45 & 4.39 \\
\hline 26 & 4.37 & 4.44 & 4.46 & 4.45 & 4.45 & 4.38 & 4.33 & 4.24 & 4.24 & 4.38 & 4.38 & 4.45 \\
\hline 27 & 4.36 & 4.31 & 4.43 & 4.36 & 4.35 & 4.21 & 3.99 & 3.90 & 3.91 & 4.23 & 4.24 & 4.32 \\
\hline 28 & 4.08 & 4.10 & 4.16 & 3.97 & 4.05 & 3.71 & 3.58 & 3.49 & 3.57 & 3.85 & 4.04 & 4.04 \\
\hline 29 & 3.78 & 3.82 & 3.76 & 3.62 & 3.45 & 3.25 & 3.40 & 3.16 & 3.28 & 3.68 & 3.64 & 3.58 \\
\hline 30 & 3.28 & 3.45 & 3.32 & 3.21 & 2.96 & 2.73 & 2.92 & 2.80 & 3.00 & 3.26 & 3.33 & 3.27 \\
\hline
\end{tabular}


Table A2. (b) Standard deviation $\left(\times 10^{12} \mathrm{~mol} / \mathrm{cm}^{3}\right)$.

\begin{tabular}{|c|c|c|c|c|c|c|c|c|c|c|c|c|}
\hline $\begin{array}{l}\text { Height } \\
(\mathrm{km})\end{array}$ & Jan & $\mathrm{Feb}$ & Mar & April & May & June & July & Aug & Sep & Oct & Nov & Dec \\
\hline 1 & 0.07 & 0.07 & 0.07 & 0.06 & 0.04 & 0.05 & 0.06 & 0.03 & 0.03 & 0.06 & 0.09 & 0.09 \\
\hline 2 & 0.05 & 0.07 & 0.05 & 0.07 & 0.03 & 0.04 & 0.05 & 0.07 & 0.06 & 0.05 & 0.07 & 0.09 \\
\hline 3 & 0.10 & 0.10 & 0.07 & 0.10 & 0.07 & 0.06 & 0.09 & 0.16 & 0.10 & 0.06 & 0.08 & 0.13 \\
\hline 4 & 0.12 & 0.06 & 0.09 & 0.08 & 0.07 & 0.08 & 0.11 & 0.08 & 0.13 & 0.06 & 0.07 & 0.14 \\
\hline 5 & 0.10 & 0.10 & 0.11 & 0.12 & 0.07 & 0.09 & 0.07 & 0.11 & 0.12 & 0.05 & 0.10 & 0.12 \\
\hline 6 & 0.12 & 0.10 & 0.10 & 0.07 & 0.07 & 0.10 & 0.08 & 0.09 & 0.13 & 0.05 & 0.10 & 0.08 \\
\hline 7 & 0.09 & 0.12 & 0.09 & 0.06 & 0.06 & 0.11 & 0.09 & 0.10 & 0.13 & 0.06 & 0.07 & 0.12 \\
\hline 8 & 0.11 & 0.10 & 0.07 & 0.05 & 0.08 & 0.08 & 0.06 & 0.07 & 0.10 & 0.08 & 0.06 & 0.13 \\
\hline 9 & 0.10 & 0.10 & 0.09 & 0.08 & 0.08 & 0.08 & 0.08 & 0.06 & 0.09 & 0.08 & 0.08 & 0.11 \\
\hline 10 & 0.11 & 0.09 & 0.07 & 0.05 & 0.14 & 0.09 & 0.09 & 0.09 & 0.09 & 0.10 & 0.03 & 0.11 \\
\hline 11 & 0.11 & 0.08 & 0.04 & 0.08 & 0.09 & 0.06 & 0.07 & 0.10 & 0.07 & 0.13 & 0.05 & 0.10 \\
\hline 12 & 0.08 & 0.09 & 0.08 & 0.11 & 0.12 & 0.05 & 0.07 & 0.04 & 0.07 & 0.06 & 0.04 & 0.07 \\
\hline 13 & 0.08 & 0.08 & 0.08 & 0.09 & 0.09 & 0.05 & 0.06 & 0.06 & 0.08 & 0.08 & 0.08 & 0.09 \\
\hline 14 & 0.08 & 0.06 & 0.07 & 0.04 & 0.06 & 0.05 & 0.05 & 0.08 & 0.04 & 0.04 & 0.03 & 0.08 \\
\hline 15 & 0.06 & 0.05 & 0.07 & 0.06 & 0.04 & 0.05 & 0.06 & 0.06 & 0.05 & 0.05 & 0.04 & 0.08 \\
\hline 16 & 0.07 & 0.04 & 0.04 & 0.05 & 0.04 & 0.05 & 0.08 & 0.04 & 0.05 & 0.07 & 0.05 & 0.07 \\
\hline 17 & 0.08 & 0.06 & 0.07 & 0.07 & 0.03 & 0.07 & 0.07 & 0.09 & 0.07 & 0.08 & 0.12 & 0.09 \\
\hline 18 & 0.09 & 0.09 & 0.11 & 0.09 & 0.06 & 0.11 & 0.10 & 0.06 & 0.15 & 0.11 & 0.11 & 0.14 \\
\hline 19 & 0.21 & 0.15 & 0.13 & 0.11 & 0.06 & 0.20 & 0.23 & 0.19 & 0.08 & 0.13 & 0.11 & 0.19 \\
\hline 20 & 0.19 & 0.11 & 0.15 & 0.23 & 0.16 & 0.36 & 0.27 & 0.28 & 0.24 & 0.22 & 0.21 & 0.32 \\
\hline 21 & 0.15 & 0.15 & 0.13 & 0.19 & 0.18 & 0.34 & 0.24 & 0.27 & 0.34 & 0.27 & 0.23 & 0.26 \\
\hline 22 & 0.20 & 0.13 & 0.13 & 0.12 & 0.17 & 0.36 & 0.14 & 0.28 & 0.31 & 0.26 & 0.22 & 0.28 \\
\hline 23 & 0.19 & 0.14 & 0.14 & 0.12 & 0.22 & 0.22 & 0.24 & 0.30 & 0.38 & 0.19 & 0.16 & 0.20 \\
\hline 24 & 0.22 & 0.19 & 0.16 & 0.17 & 0.24 & 0.13 & 0.21 & 0.16 & 0.31 & 0.16 & 0.16 & 0.18 \\
\hline 25 & 0.18 & 0.11 & 0.15 & 0.14 & 0.14 & 0.13 & 0.13 & 0.13 & 0.15 & 0.14 & 0.12 & 0.18 \\
\hline 26 & 0.16 & 0.11 & 0.17 & 0.17 & 0.15 & 0.22 & 0.22 & 0.16 & 0.15 & 0.15 & 0.10 & 0.15 \\
\hline 27 & 0.16 & 0.10 & 0.13 & 0.15 & 0.17 & 0.20 & 0.25 & 0.18 & 0.15 & 0.23 & 0.11 & 0.14 \\
\hline 28 & 0.15 & 0.16 & 0.16 & 0.28 & 0.21 & 0.27 & 0.18 & 0.15 & 0.18 & 0.30 & 0.13 & 0.18 \\
\hline 29 & 0.17 & 0.14 & 0.20 & 0.29 & 0.33 & 0.17 & 0.29 & 0.09 & 0.21 & 0.27 & 0.16 & 0.17 \\
\hline 30 & 0.15 & 0.15 & 0.21 & 0.25 & 0.28 & 0.18 & 0.30 & 0.06 & 0.36 & 0.27 & 0.22 & 0.20 \\
\hline
\end{tabular}

Acknowledgements. Laboratoire de l'Atmosphère et des Cyclones (LACy) is supported by the French Centre National de la Recherche Scientifique (CNRS)/Institut National des Sciences de l'Univers (INSU) and the Conseil Régional de la Réunion. INSU/CNRS and SHADOZ/NASA programs financially support the Radiosonde launching. One of the authors, VSK acknowledges Conseil Régional de la Réunion and French Centre National de la Recherche Scientifique (CNRS)/Institut National des Sciences de 1'Univers (INSU) for the financial grant obtained under the post-doctoral fellowship scheme. We are also grateful to the LACy radio-sounding team (especially F. Posny, J.-M. Metzger and G. Bain) for their constant co-operation in launching radiosondes. Authors are thankful to the Upper Atmosphere Research Satellite (UARS) Project, (Code 916), and the Distributed Active Archive Center (Code 902) at the Goddard Space Flight Center, Greenbelt, MD 20771 for providing HALOE satellite data through the web site http://haloedata.larc. nasa.gov/home/index.php. We also express our thanks to SAGE-II, TOMS and SAOZ data centres for providing access to the data.

Topical Editor F. D'Andrea thanks two anonymous referees for their help in evaluating this paper.

\section{References}

Attmannspacher, W., Noe, J., Muer, D., Lenoble, J., Megie, G., Pelon, J., Pruvost, P., and Reiter, R.: European Validation of SAGE II Ozone Profiles, J. Geophys. Res., 94, 8461-8466, 1989.

Baldy, S., Ancellet, G., Bessafi, M., Badr, A., and Lan Sun Luk, D.: Field observations of the vertical distributions of tropospheric ozone at the island of la reunion (southern tropics), J. Geophys. Res., 101, 23 835-23 849, 1996.

Baray, J.-L., Ancellet, G., Randriambello, T., and Baldy, S.: Tropical cyclone marlene and stratosphere-troposphere exchange, J. Geophys. Res., 104, 13 953-13 970, 1999.

Baray, J.-L., Daniel, V., Ancellet, G., and Legras, B.: Planetaryscale tropopause folds in the southern subtropics, Geophys. Res. Lett., 27, 353-356, 2000.

Barnes, R. A., Bandy, A. R., and Torres, A. L.: Electrochemical concentration cell ozonesonde accuracy and precision, J. Geophys. Res., 90, 7881-7887, 1985.

Bencherif, H., Portafaix, T., Baray, J.-L., Morel, B., Baldy, S., Leveau. J., Hauchecorne, A., Keckhut, P., Moorgawa, A., Michaelis, M., and Diab, R.: Lidar observations of lower stratospheric 
aerosols over South Africa linked to large scale transport across the southern subtropical barrier, J. Atmos. Solar Terr. Phys., 65, 707-715, 2003.

Beekmann, M., Ancellet, G., Megie, G., Smit, J. H. G., and Kley, D.: Inter comparison campaign including electrochemicals sondes of ECC and Brewer-Mast type and a ground based UVdifferential absorption lidar, J. Atmos. Chem., 19, 259-288, 1994.

Bhatt, P. P., Remsberg, E. E., Gordley, L. L., McInerney, J. M., Bracket, V. G., and Russel III, J. M.: An evaluation of the quality of Halogen Occultation Experiment ozone profiles in the lower stratosphere, J. Geophys. Res., 104, 9261-9275, 1999.

Bodeker, G. E., Scott, J. C., Kreher, K., and McKenzie, R. L.: Global ozone trends in potential vorticity coordinates using TOMS and GOME intercompared against the Dobson network: 1978-1998, J. Geophys. Res., 19, 23 029-23 042, 2001.

Borchi, F., Pommereau, J.-P., Garnier, A., and Pinharanda, M.: Evaluation of SHADOZ sondes, HALOE and SAGE II ozone profiles at the tropics from SAOZ UV-Vis remote measurements onboard long duration balloons, Atmos. Chem. Phys. Discuss., 4, 4945-4997, 2004, http://www.atmos-chem-phys-discuss.net/4/4945/2004/.

Brinksma, E. J., Bergwerff, J. B., Bodeker, G. E., Boersma, K. F., Boyd, I. S., Connor, B. J., Hann, J. F., Hogervorst, W., Hovenier, J. W., Parrish, A., Tsou, J. J., Zawodny, J. M., and Swart, D. P. J.: Validation of 3 years of ozone measurements over Network for the Detection of Stratospheric Change station Lauder, New Zealand, J. Geophys. Res., 105, 17 291-17 306, 2000.

Brinksma, E. J., Ajtic, J., Bergwerff, J. B., Bodeker, G. E., Boyd, I. S., Haan, J. F., Hogervorst, W., Hovernier, J. W., and Swart, D. P. J.: Five years of observations of ozone profiles over Lauder, New Zealand, J. Geophys. Res., 107(D14), 4216, doi:10.1029/2001JD000737, 2002.

Brühl, C., Drayson, S. R., Russell III, J. M., Crutzen, P. J., McInerney, J., Purcell, P. N., Claude, H., Gernand, H., McGee, T., McDermid, I., and Gunson, M. R.: HALOE Ozone Channel Validation, J. Geophys. Res., 101, 10 217-10 240, 1996.

Chandra, S., Varotsos, C., and Flynn, L. E.: The mid-latitude total ozone trends in the northern hemisphere, Geophys. Res. Lett, 23, 555-558, 1996.

Chandra, S., Ziemke, J. R., Bhartia, P. K., and Martin, R. V.: Tropical tropospheric ozone: Implications for dynamics and biomass burning, J. Geophys. Res., 107(D14), 4188, doi:10.1029/2001JD000447, 2002.

Cunnold, D. M., Chu, W. P., Barnes, R. A., McCormick, M. P., and Veiga, R. E.: Validation of SAGE II Ozone Measurements, J. Geophys. Res., 94, 8447-8460, 1989.

Cunnold, D. M., Froidevaux, L., Russell III, J. M., Connor, B. J., and Roche, A. E.: Overview of UARS Ozone Validation Based Primarily on Intercomparisons Among UARS and SAGE II Measurements, J. Geophys. Res., 101, 10 335-10 350, 1996.

Cunnold, D. M., Newchurch, M. J., Flynn, L. E., Wang, H. J., Russell, J. M., McPeters, R., Zawodny, J. M., and Froidevaux, L.: Uncertainties in upper stratospheric ozone trends from 1979 to 1996, J. Geophys. Res., 105, 4427-4444, 2000.

Dorokhov, V. M., Khaikin, S. M., and Igantiev, D. V.: Observations of ozone variability over eastern Siberia: Yakutsk, 1992-2002, Air pollution research report, 79, Proceedings of the 6th European symposium, 128-131, 2002.
Fishman, J., Watson, C. E., Larsen, J. C., and Logan, J. A.: Distribution of tropospheric ozone determined from satellite data, J. Geophys. Res., 95, 3599-3617, 1990.

Fujiwara, M., Kita, K., Ogawa, T., Kawakami, S., Sano, T., Komala, N., Saraspriya, S., and Suripto, A.: Seasonal variations of tropospheric ozone in Indonesia revealed by 5-year ground-based observations, J. Geophys. Res, 105, 1879-1888, 2000.

Fujiwara, M. Tomikawa, Y., Kita, K., Kondo, Y., Komala, N., Saraspriya, S., Manki, T., Suripto, A., Kawakami, S., Ogawa, T., Kelana, E., Suhardi, B., Harijono, S. W. B., Kudsy, M., Sribimawati, T., and Yamanaka, M. D.: Ozonesonde observations in the Indonesian maritime continent: a case study on ozone rich layer in the equatorial upper troposphere, Atmos. Environ., 37, 353-362, 2003.

Grooss, J.-U., Mueller, R., Becker, G., McKenna, D. S., and Crutzen, P. J.: The upper stratospheric ozone budget: An update of calculations based on HALOE data, J. Atmos. Chem., 34, 171-183, 1999.

Hoffman D. J., Bonasoni, P., De Maziere, M., et al.: Intercomparison of UV/visible spectrometers for measurements of stratospheric $\mathrm{NO}_{2}$ for the Network for the Detection of Stratospheric Changes, J. Geophy. Res., 100, 16765-16791, 1995.

Kim, J. H. and Newchurch, M. J.: Climatology and trends of tropospheric ozone over the eastern Pacific Ocean: The influences of biomass burning and tropospheric dynamics, Geophys. Res. Lett., 23, 3723-3726, 1996.

Kirchhoff, V. W. J. H., Barnes, R. A., and Torres, A. L.: Ozone climatology at Natal, Brazil, from in situ ozonesonde data, J. Geophys. Res., 96, 10 899-10 909, 1991.

Kita, K., Fujiwara, M., and Kawakami, S.: Total Ozone increase associated with forest fires over the Indonesian region and its relation to the EI Nino-Southern Oscillation, Atmos. Environ., 34, 2681-2690, 2000.

Komhyr, W. D., Barnes, R. A., Brothers, G. B., Lathrop, J. A., and Opperman, D. P.: Electrochemical concentration cell ozonesonde performance evaluation during STOIC 1989, J. Geophys. Res., 100, 9231-9244, 1995.

Lelieveld, J. and Dentener, F. J.: What controls tropospheric ozone?, J. Geophys. Res., 105, 3531-3551, 2000.

Logan, J.A., and Kirchhoff, V.W.J.H.: Seasonal variations of tropospheric ozone at Natal, Brazil, J. Geophys. Res., 91, 7876-7881, 1986.

Logan, J. A.: An analysis of ozonesonde data for the lower stratosphere: Recommendations for testing models, J. Geophys. Res., 104, 16 151-16 170, 1999.

Lu, J., Mohnen, V. A., Yue, G. K., Atkinson, R. J., and Matthews, W. A.: Intercomparison of stratospheric ozone profiles obtained by stratospheric aerosol and gas experiment II, Halogen Occultation Experiment and ozonesondes in 1994-95, J. Geophys. Res., 102, 16 137-16 144, 1997.

Marufu, L., Dentener, F., Lelieveled, J., Andreae, M. O., and Helas, G.: Photochemistry of the African troposphere: Influence of biomass burning emission, J. Geophys. Res., 104, 14513 14 530, 2000.

Masserot, D., Lenoble, J., Brogniez, C., Houet, M., Krotkov, N., and McPeters, R.: Retrieval of ozone column from global irradiance measurements and comparison with TOMS data. A year of data in the Alps, Geophys. Res. Lett., 29, 1309, doi.10:1029/2002GL014823, 2002. 
McPeters, R. D., Kruegar, A. J., Bharatia, P. K., Herman, J. R., Ozkes, A., Ahmad, Z., Cebula, R. P., Schlesinger, B. M., Swissler, T., Taylor, S. L., Torres, O., and Wellemeyer, C. G.: Nimbus-7 total ozone mapping spectrometer (TOMS) data products user's guide, NASA Ref. Pub. 1323, 1993.

McCormick, M. P., Zawodny, J. M., Veiga, R. E., Larsen, J. C., and Wang, P. H.: An overview of SAGE I and SAGE II ozone measurements, Planet Space Sci., 37, 1567-1586, 1989.

Morris, G. A., Gleason, J. F., Russell III, J. M., Schoeberl, M. R., and McCornick, M. P.: A comparison of HALOE V19 with SAGE II V6.00 ozone observations using trajectory mapping, J. Geophys. Res., 107, 4177, doi:10.1029/2001JD000847, 2002.

Moxim, W. J. and Levy II, H.: A model analysis of tropical South Atlantic Ocean tropospheric ozone maximum: The interaction of transport and chemistry, J. Geophys. Res., 104, 17 393-17415, 2000.

Naujokat, B: An update of the observed quasi-biennial oscillation of the stratospheric winds over the tropics, J. Atmos. Sci., 43, 1873-1877, 1986.

Natarajan, M. and Callis, L. B.: Ozone Variability in the High Latitude Summer Stratosphere, Geophys. Res. Lett., 24, 1191-1194, 1997.

Newchurch, M. J., Bishop, L., Cunnold, D., et al.: Upperstratospheric ozone trends 1979-1998, J. Geophys. Res., 105, 14 625-14 636, 2000.

Pommereau, J. P. and Goutail, F.: $\mathrm{O}_{3}$ and $\mathrm{NO}_{2}$ ground-based measurements by visible spectrometry during arctic winter and spring 1988, Geophys. Res. Lett., 15, 891-894, 1988.

Pommereau, J. P. and Piquard, J.: Ozone, nitrogen dioxide and aerosol vertical distribution by UV-visible solar occultation from balloons, Geophys. Res. Lett, 21, 1227-1230, 1994.

Portafaix T., Morel, B., Bencherif, H., Baldy, S., GodinBeekmann, S., and Hauchecorne, A.: Fine-scale study of a thick stratospheric ozone lamina at the edge of the southern subtropical barrier, J. Geophys. Res., 108(D6), 4196, doi:10.1029/2002JD002741, 2003.

Randel, W. J., Wu, F., Russell III, J. M., Waters, J. W., and Froidevaux, L.: Ozone and Temperature Changes in the Stratosphere Following the Eruption of Mt. Pinatubo, J. Geophys. Res., 100, 16753-16764, 1995.

Randriambelo, T., Baray, J.-L., and Baldy, S.: Effect of biomass burning, convective venting and transport on tropospheric ozone over the Indian Ocean: Reunion Island field observations, J. Geophys. Res., 105, 11 813-11 832, 2000.

Remsberg, E., Bhatt, P., and Deaver, L. E.: Ozone changes in the lower stratosphere from the halogen occultation experiment for 1991 through 1999, J. Geophys. Res., 106, 1639-1653, 2001.

Rood, R. B., Douglass, A. R., Cerniglia, M. C., Sparling, L. C., and Nielsen, J. E.: Seasonal variability of middle-latitude ozone in the lowermost stratosphere derived from probability distribution functions, J. Geophys. Res., 105, 17 793-17 805, 2000.

Roscoe, H. K., Johnston, P. V., Van Roozendael, M., et al.: Slant column measurements of $\mathrm{O} 3$ and NO2 during the NDSC intercomparison of zenith-sky UV-visible spectrometers in june 1996, J. Atmos. Chem., 32, 281-314, 1999.

Russell III, J. M., Gordley, L. L., Park, J. H., Drayson, S. R., Hesketh, W. D., Cierone, R. J., Tuck, A. F., Frederick, J. E., Harries, J. E., and Crutzen, P. J.: The Halogen Occultation Experiment, J.
Geophys. Res., 98, 10777-10 797, 1993.

Sarkissian, A.: Observation depuis le sol des nuages et des poussières dans l'atmosphère: Applications a la stratosphère polaire et à l'atmosphère de Mars, Thèse de Doctorat de l’Université Paris 6, 1992.

Sarkissian, A., Vaughan, G., Roscoc, H. K., Bartlett, L. M., Connor, F. M. O., Drew, D. G., Hughes, P.A., and Moore, D. M.: Accuracy of measurements of total ozone by a SAOZ ground-based zenith sky visible spectrometer, J. Geophys. Res., 102, 13791390, 1997.

Semane, N., Bencherif, H., Morel, B., Hauchecorne, A., and Diab, R. D.: An unusual stratospheric ozone decrease in the southern hemisphere subtropics linked to isentropic air-mass transport as observed over Irene $\left(25.5^{\circ} \mathrm{S}, 28.1^{\circ} \mathrm{E}\right)$ in mid-May 2002, Atmos. Chem. Phys., 6, 1927-1936, 2006, http://www.atmos-chem-phys.net/6/1927/2006/.

Shiotani, M., Fujiwara, M., Hashizume, H., Vomel, H., Oltmans, S. J., and Watanabe, T.: Ozonesonde Observations in the Equatorial Eastern Pacific - the Soyo-Maru Survey, J. Met. Soc. Japan, 88, 897-909, 2002.

Sivakumar, V., Baray, J.-L., Baldy, S., and Bencherif, H.: Tropopause characteristics over a southern sub-tropical site, Reunion Island $\left(21^{\circ} \mathrm{S}, 55^{\circ} \mathrm{E}\right)$ : using Radiosonde/Ozonesonde data, J. Geophys. Res., 111, D19111, doi:10.1029/2005JD006430, 2006.

Staehelin, J. N., Harris, R. P., Appenzeller, C., and Eberhard, J.: Ozone trends: A review, Rev. Geophys., 39, 231-290, 2001.

Thompson, A. M., Witte, J. C., McPeters, R. D., Oltmans, S. J., Schmidlin, F. J., Logan, J. A., Fujiwara, M., Kirchhoff, V. W. J. H., Posny, F., Coetzee, G. J. R., Hoegger, B., Kawakami, S., Ogawa, T., Johnson, J. B., Vömel, H., and Labow, G.: Southern Hemisphere Additional Ozonesondes (SHADOZ) 1998-2000 tropical ozone climatology 1. Comparison with Total Ozone Mapping Spectrometer (TOMS) and ground-based measurements, J. Geophys. Res., 108, 8238, doi:10.1029/2001JD000967, 2003a.

Thompson, A. M., Witte, J. C., Oltmans, S. J., Schmidlin, F. J., Logan, J. A., Fujiwara, M., Kirchhoff, V. W. J .H., Posny, F., Coetzee, G. J. R., Hoegger, B., Kawakami, S., Ogawa, T., Fortuin, J. P. F., and Kelder, H. M.: Southern Hemisphere Additional Ozonesondes (SHADOZ) 1998-2000 tropical ozone climatology 2. Tropospheric variability and the zonal wave-one, J. Geophys. Res., 108, 8241, doi:10.1029/2002JD002241, 2003b.

Tiao, G. C., Reinsel, G. C., Pedrick, J. H., Allenby, G. M., Mateer, C. L., Miller, A. J., and DeLuisi, J. J.: A statistical trend analysis of ozonesonde data, J. Geophys. Res., 91, 13 121-13 136, 1986.

Vaughan, G., Roscoe, H. K., Bartlett, L. M., et al.: An intercomparison of ground-based UV-visible sensors of ozone and $\mathrm{NO}_{2}$, J. Geophys Res, 102, 1411-1422, 1997.

WMO (World Meterological Organisation): SPARC/IOC/GAW: Assessment of trends in the vertical distribution of ozone, edited by: Harris, N., Hudson, R., and Phillips, C., SPARC report $\mathrm{N}^{\circ} 1$, WMO: Ozone research and monitoring project, Rep. 43, 1998.

WMO: Scientific Assessment of Ozone Depletion: 1998, Rep. 44, Global Ozone Res. and Monit. Proj., Geneva, 1999.

Ziemke, J. R. and Chandra, S.: Seasonal and interannual variabilities in tropical tropospheric ozone, J. Geophys. Res., 104, $21425-21442,1999$. 